\title{
Estimating genetic variability, gene effect, heritability, and genetic advance of yield component agronomic traits: towards the improvement of peanut agronomic traits
}

\section{Addisu Getahun,}

Email: addisu.getahun@inu.edu.et /addisu.getahun@aastu.edu.et

Plant Breeding and Genetics Program, Department of Plant Sciences, Bahir Dar University (BDU)

Agricultural Biotechnology Program, Department of Biotechnology, Addis Ababa Science \& Technology

University (AASTU)

Department of Plant Sciences, College of Agriculture, Food and Climate Sciences Injibara University (IU)

Department of Crop Genetics and Breeding, College of Agronomy, Agricultural University of Hebei, Baoding P.R. China

Pawe Agricultural Research Center (PARC), Ethiopian Institute Agricultural Research (EIAR)

\begin{abstract}
Background: Peanut is an important oil and legume food crop for human and feed for livestock. Peanut yield association characters like pod and seed traits are the most widely targeted parameter. Peanut yield is a function of growth rate, duration of reproductive growth, and the fraction of crop growth rate which are partitioned toward pod yield. For effective selection, heritability along with genetic advance is more useful than the estimation of only heritability.
\end{abstract}

Methods: The present study field design was laid out using single row and single plot techniques. Pod length, pod width, pod length by width, seed length, seed width, seed length by width yield contributing data were collected both from two parents and 251 RIL populations across two locations in two consecutive cropping seasons (2015/2016 \& 2016/2017). Data analysis was computed through SAS ver.9.4 and PBTools ver.1.4.

Results: The highest genotypic coefficient of variation was found in pod length (22.47), number of pods per plant (23.66), pod yield per plant (28.43), multiple seedpods per plant (30.44). The highest narrow sense heritability was found in seed length (66\%), pod length by width (87\%), and pod thickness (93\%), meanwhile, the highest broad sense heritability values have been recorded in seed length (99\%), seed length by width (99\%), number of pods per plant (95\%), shelling percentage (94\%), pod thickness (93\%), thickness of pod shells (92), seed yield per plant (89\%), seed thickness (87\%), seed width (83\%), multiple seedpods per plant (79\%), and pod weight per plant (75\%). The highest genetic advance as percent of mean values occurred in multiple seedpods per plant (215.44), number of pods per plant 
(85.28), pod yield per plant (64.90), seed yield per plant (63.49), thickness of pod shells (56.87), pod length by width (36.55), seed length by width (30.98), and seed length (23.26).

Conclusions: Additive gene effects were observed in the traits of seed length, seed length by width, pod length, pod width, pod length by width, pod thickness, thickness of pod shells, and multiple seedpods per plant. The highest broad sense heritability values coupled with high genetic gain were estimated in multiple seedpods per plant, number of pods per plant, pod weight plant, seed weight per plant, thickness of pod shells, pod length by width, seed length by width. Therefore, in the present study, use more pod and seed-related traits than the previous findings.

Key words: Peanut; Heritability; Genetic advance, Additive gene effect; Dominant gene effect, PBTools;

\section{Introduction}

Peanut (Arachis hypogaea L.) is one of the kings of oilseeds with a multi-purpose legume crop grown and highly consumed in arid and semi-arid regions of the world. It is an economically important and versatile crop for resource-poor farmers in Asia and Africa that offers a rich source of oil, protein, minerals (Ca, Mg, P and K), and vitamins (E, K and B1) (Prabhu, Divyadharsini, and Manivannan 2015). Yield and yield contributing parameters are the most widely targeted traits of peanut improvement program across the globe. Peanut pod yield is a function of crop growth rate, duration of reproductive growth, and the fraction of crop growth rate partitioned toward pod yields. Therefore, understanding of physiology of yield is also essential for better target yield increase in crop including peanut. The main important yield contributing attributed traits are pod yield per plant, number of pods per plant, and 100seed weight (Janila et al. 2013).

In peanut genetic variability is very low due to the origin of a single hybridization event between two different diploid species followed by a chromosome doubling and crossing barriers with wild diploid species due to the variation of ploidy nature. The cultivated groundnut is an allotetraploid, while all wild Arachis species are diploid except A. monticola and certain species in Section Rhizomatosae. The low genetic variability for the traits of interest and polyploidy nature are a major bottleneck for peanut improvement breeding strategies. The cultivated accession of Arachis hypogaea in the gene banks and the advanced breeding lines are frequently used as sources of variability used as parents in hybridization (Janila et al. 2013).

Segregating populations derived from crossing two parents are most common in peanut breeding programs. In peanut improvement program, segregating populations derived from hybridization through 
pedigree and bulk-pedigree methods of breeding are the most common. Pedigree selection method allows breeders to practice selection of the best traits with high heritability values such as plant type, pod and seed-related traits and the testa color in early filial generations. Selection of quantitative traits such as yield and seed composition characters made in later generations. Bulk-pedigree method is a modified method of bulk aimed at improving traits with low heritability traits (Wynne and Gregory, 1981). Single seed decent method is becoming popular and it has the advantage to save space and resources (Isleib et al. 1994). GxE has a considerable influence on the progress of crop improvement. In peanut, a majority of important agronomic traits is polygenic nature and highly influenced by environment that hinders the achievable genetic gains in breeding programs. Genetic analysis of yield has revealed by the highly influence of the environment on pod yield traits (Zhang et al. 2011). High yielding cultivars with the least gxe interactions are normally desirable. However, when a cultivar is to be selected for a specific environment the gxe interaction is desirable for maximizing production (Janila et al. 2013).

Heritability is an idea of how much of the variation is available in a trait due to genetic factors. High heritability indicates a strong similarity between parents and their respective offspring with regard to a specific trait, while low heritability implies that low level of resemblance between them. The combined effect of all loci, including possible allelic interactions within each locus (dominance) and between loci (epistasis) is the effect of genotypic value. The effect of a particular allele on a trait is depends on the allele's frequency in the population and the effect of each genotype that includes all the allele. This is sometimes called as the average effect of an allele. The additive genetic value of an individual population called the breeding value is the sum of the average effects of all the alleles (Falconer \& Mackay, 1996). According to the principles of Mendelian law of segregation one allele from each locus is present in each gamete cell, and in this way, additive genetic information are transferred from parents to offspring. Certainly in the reason of each offspring receives a different set of alleles from its parents, half of the additive genetic variance in the population occurs within families.

Narrow sense heritability is the proportion of phenotypic variance among individual population that is due to heritable genetic effects (additive). Broad sense heritability can estimated as the proportion of phenotypic variances directly attributable to the effect of the whole genotype, it comprising the sum total of additive, dominance and epistatic variance components (Nyquist 1991; Falconer and Mackay 1996). Heritability is a key parameter for quantitative genetics because it determines the response to selection. In the field of plant, breeding there are many different selection principles, and mating designs and the possibility of observational units are quite diverse, which are ranging from individual plant population to a 
means of genotypes tested across multiple environments. Normally, no difference is made between broadand narrow-sense heritability; however, narrow-sense $\left(h^{2}\right)$ heritability is most important in animal and plant selection programs, because response to artificial natural selection depends on additive genetic variance. Moreover, resemblance between relatives is mostly driven by additive genetic variance (Hill et al. 2008). The values of heritability should be lies between 0 and 1 . For example, narrow-sense heritability for humans' height is estimated 0.8 (Macgregor et al. 2006; Visscher et al. 2008).

Naturally, variation is classified into three main types such as phenotypic, genotypic, and environmental. Mather and Jinks (1982) stated that phenotypic variation is dividing into three main features viz; (1) heritable fixable (additive variance), (2) heritable non-fixable (dominance and epistasis variance) and (3) non-heritable non-fixable (environmental variance). Actually, the heritable fixable component of phenotypic variance will be included in additive $\mathrm{x}$ additive fraction of the epistasis variances. The genetic variances are consists of additive, dominance and epistasis components. In advance, the total phenotypic variations might be divided into (1) fixable (additive and additive $\mathrm{x}$ additive), (2) nonfixable (dominance, additive $\mathrm{x}$ dominance, dominance $\mathrm{x}$ dominance types of epistasis, and environmental fraction) components (Singh and Narayana 1990, 1993; Singh and Chaudary, 1999). Cockerham (1961) also reported the epistatic variation categorized as additive $\mathrm{x}$ additive, additive $\mathrm{x}$ dominance and dominance $\mathrm{x}$ dominance variances components. Many previous studies showed that epistatic gene action or non-allelic interaction effects in the inheritance of quantitative traits are very important for plant breeders' to select promising and outstanding plant population (Khattak et al. 2002; Sharma et al. 2003; Rebetzke et al. 2004; Sood et al. 2004).

Genetic variation is very important to maintain the level of high productivity crops including peanut breeding programs (Tripathi et al. 2013). The occurrence and continuation of genetic variability is an important tool for crop improvement strategies, however, the loss of locally available land race and adapted germplasm resources has rapid and high, which need to be keep in sustainable conditions (Harlan, 1975). A critical estimation of genetic variability is a precondition for promoting crop improvement strategy and adopting appropriate selection systems (Dhanwani et al. 2013). The genetic variability is determined with the help of certain genetic parameters viz: genotypic coefficient of variation, phenotypic coefficient of variation and heritability. For selection, heritability along with genetic advance is more useful than the heritability estimates alone (Johnson et al. 1955; Cholin et al. 2010; Shinde et al. 2010 and Meshram et al. 2013). 
Genetic variability is also the basic tools for crop improvement programs as comprises and provides wider scope for selection. The effectiveness of selection is depending on the nature, extent and magnitude of genetic variability present in the given population with the existence of inheritance between parents and offsprings. The variability in the population is largely due to genetic than environmental effect; the possibility of selecting superior genotypes are a prerequisite for obtaining high yield, which is the ultimate expression of various yield-association characters. Therefore, sometimes-direct selection based on high yielding potential could be not effective (Islam and Rasul 1998). Sometimes very difficult to understand proportion of observed variability is heritable or non-heritable i.e. environmental variation affect our selection procedure directly and indirectly. The process of breeding in the population is primarily conditioned by magnitude and nature of interactions of genotype and environment in the given plant characters. Therefore in the present study the components of variance such as phenotypic and genotypic coefficient of variances, broad sense heritability $\left(H^{2}\right)$, narrow sense heritability $\left(h^{2}\right)$, and estimated genetic advance as percent of mean have computed for pod yield and seed-related traits (Shashikumara, Sanjeev, and Venkataravana 2016).

Inbred line population development, selection, and release a new promising cultivars are one of the strategies of crop improvement programs that have been contributed to increase yield and sustainable agricultural technology innovation and development. Many economically important agronomic traits are quantitative in nature. Quantitative genetic studies are usually based on a simplified model that defines the phenotypic value because of the genotypic plus the environmental effect (Allard 1971; Ramalho et al. 2000; Antonio et al. 2012).

The objectives of the present experiment were to estimate narrow sense and broad sense heritability, to estimate genotypic and phenotypic variability, to evaluate genetic advance, to estimate additive, and dominance gene effects from 251 single cross inbred line populations, which have not been reported earlier. 


\section{Materials and Methods}

\section{Field experimental and plant materials}

The present experiment was carried out using 251 RIL populations derived from the cross between silihong (female parent) and black peanut (male parent). The field trial was conducted in Baoding and Handan environments for two consecutive cropping years from 2015 to 2016 in China using randomized complete block design (RCBD). All pod and see-related phenotypic data were collected after harvesting in three repeats.

\section{Statistical analysis}

All pod and seed-related phenotypic data were subjected to system analysis software (SAS ver. 9.4, SAS Institute, USA) using PROC GLM and PROC MIXED model applied for phenotypic variance component analysis in the 251 RIL populations with the included of two parents. Genetic variance component statistical analysis was computed using Plant Breeding Tools version 1.4 software (IRRI, 2014), using single environment analysis system in the restriction maximum likelihood (REML) model and North Carolina one (NC-I) mating design.

\section{Estimation of phenotypic and genotypic variability}

Parents and offspring phenotypic and genotypic variances were estimated using the statistical formula developed by Singh, R.K. and Chaudhary, B.D (1979) and the expected mean squares under the assumption of random and fixed effect model was calculated from linear combinations of phenotypic and genotypic coefficient of variations, which were computed as per the methods suggested by Burton and Devane (1953).

Genotypic variance $\left(\sigma^{2} \mathrm{~g}\right)=\frac{\text { Msg-Mse }}{r}$

Environmental variance $\left(\sigma^{2} \mathrm{e}\right)=$ Mse

Phenotypic variance $\left(\sigma_{\mathrm{p}}^{2}\right)=\sigma_{\mathrm{g}}^{2}+\sigma_{\mathrm{e}}^{2}$

Where; $M_{s g}$ and $M_{s e}$ are the mean sum squares of the genotypes and error in the analysis of variances respectively $r$ is the number of replications. 


\section{Estimation of genotypic and phenotypic coefficient of variability}

Genotypic and phenotypic coefficient of variability was computed as per the methods given by Burton and Devane (1953).

i) Genotypic coefficient of variability $(\mathrm{GCV}): \mathrm{GCV}=\frac{\sigma 2 \mathrm{~g}}{\mathrm{x}} \times 100$

ii) Phenotypic coefficient of variability (PCV): PCV $=\frac{\sigma 2 \mathrm{p}}{\mathrm{x}} \times 100$ Where,

$\sigma 2 \mathrm{~g}=$ Genotypic standard deviation

$\sigma 2 \mathrm{p}=$ Phenotypic standard deviation

$\mathrm{X}=$ Grand mean of the traits

GCV and PCV values were categorized as low, moderate and high as indicated by Siva Subramanian and Menon (1973). It categorized as follows: 0-10\% low, 10-20 \% moderate, and $\geq 20 \%$ high

\section{A. Broad Sense Heritability $\left(H^{2}\right)$}

Broad sense heritability was computed as the ratio of genetic variance to the total phenotypic variance as suggested by Hanson et al. (1956) and expressed as in percentage.

$$
\text { Heritability }\left(H^{2}\right)=\frac{\sigma 2 \mathrm{~g}}{\sigma 2 \mathrm{p}} \times 100
$$

Where $\sigma_{\mathrm{g}}^{2}=$ Genotypic variance and $\sigma_{\mathrm{p}}^{2}=$ Phenotypic variance. The heritability percentage have been categorized as low $(0-30 \%)$, moderate $(30-60 \%)$, and high $(\geq 60 \%)$ as developed and given by Robinson et al. (1949).

\section{B. Narrow sense heritability $\left(h^{2}\right)$}

Narrow sense heritability $\left(\mathrm{h}^{2}\right)$ was estimated from parent offspring regression analysis according to the method of Anderson et al. (1991).

$$
Y=a+b x i+e i \quad \text { Where } \mathrm{e}_{\mathrm{i}}=\text { error and } \mathrm{b}=\text { the regression coefficient; i.e. } \mathrm{b}=\frac{\sigma \mathrm{xy}}{\sigma 2 \mathrm{x}}
$$

Where $\sigma_{\mathrm{xy}}=$ covariance of parent-offspring analysis and $\sigma_{\mathrm{x}}^{2}=$ total variance of parental measurements. Genetic correlation between offspring's or RIL population with parental traits determined according to the method suggested and given by Kwon and Torrie (1964):

$$
\mathrm{rg}=\frac{\text { Covgij }}{(\sigma 2 \mathrm{gi} \times \sigma 2 \mathrm{gj})}
$$

$\operatorname{Cov} \mathrm{gij}$ and $\sigma^{2} \mathrm{gj}$ are the estimates of covariance and variance for traits $i$ and $j$.

$$
\text { Heritability }\left(\mathrm{h}^{2}\right)=\frac{\sigma 2 \mathrm{a}}{\sigma 2 \mathrm{p}} \times 100
$$


Where $\sigma_{\mathrm{a}}^{2}=$ Additive variances and $\sigma_{\mathrm{p}}^{2}=$ Phenotypic variances

\section{Estimated genetic advance}

Genetic advance under selection was suggested and estimated using the formula given by (Johnson et al. 1955).

$$
\mathrm{EGA}=\mathrm{H}^{2} \mathrm{k} \sigma \mathrm{p}
$$

Where, $\mathrm{H}^{2}=$ Heritability in broad sense

$\mathrm{k}=$ Selection differential which is equal to 2.06 at $5 \%$ selection intensity (Lush, 1949).

$\sigma p=$ Phenotypic standard deviation.

\section{Genetic advance as percent of mean}

Genetic advance as percent of mean has calculated according to the formula given by (Johnson et al. 1955).

$$
\mathrm{GAM}=\frac{\mathrm{GA}}{\mathrm{X}} \times 100
$$

Where, $\mathrm{GA}=$ Genetic advance, and $\mathrm{X}=$ General mean of the characters/traits

Genetic advance as percent of mean was categorized as low, moderate and high as given by (Johnson et al. 1955). It described, as 0-10\% low; 10-20\% moderate and $\geq 20 \%$ high.

\section{Result and discussion}

\section{Genotypic and phenotypic variability}

The two basic requirements of plant breeding are the presence of genetic variation and exploitation of the existed variation through the method of selection. The presence of genetic variation in a character is necessary for any improvement in that character. Selection is the second basic step in crop improvement breeding programs. Selection involves in the identification and isolation of desirable plants from a vast and variable population. The progeny from selected plants may be released as a variety if they are found suitable and superior to the existing varieties and controls in yield and other important parameters to full fill the requirements of consumers or farmers need. Selection of plants from a population is usually based on their phenotypic performance.

Phenotypic variation has both heritable and non-heritable components that included environmental effects. Moreover, heritable component is due to the genes present in the existed plant population. One or groups of economically important gene(s) mainly control the development of quantitative and qualitative traits. However, the genes cannot able to produce characters directly. In the present study, the highest genotypic coefficient of variation $(>10 \%)$ was found in the traits of pod length (22.47), number of pods 
per plant (23.66), pod weight per plant (28.43), multi-seedpods per plant (30.44), and moderate genetic variation was recorded in the traits of seed weight per plant (19.04). The highest phenotypic coefficient of variation $(>10 \%)$ had been scored in the traits of pod number per plant (23.99), pod length (25.40), seed weight per plant (29.75), multiple seedpods per plant (30.44), pod weight per plant (41.29). In the previous studies similar findings have been reported on genotypic and phenotypic coefficient of variability in pod and seed related traits such as Shashikumara et al (2016) reported that high GCV and PCV found in pod and seed-related yields traits, such as pod yield, kernel yield, matured pods and oil yield per plant (Lal et al. 2003; Golakia et al. 2005; and Veeramani et al. 2005). Therefore, our selection focused on superior transgressive populations based on their high to moderate genetic advance, heritability and phenotypic variation values.

\section{Analysis of phenotypic variances for pod and seed-related traits}

In the present study, we have used 251 RIL populations with two parents as a check for phenotyping in pod and seed-related agronomic traits in two tested environments for testing genetic and phenotypic variations and confirming the expected null hypothesis $\left(H_{0}\right)$ through F-test statistics. The statistical procedures were computed in the combined estimation of analysis of variances from pod and seed-related traits across environments and within consecutive cropping seasons. Based on system analysis software (SAS ver. 9.0) variance analysis matrix of Fcalculated statistics result the null hypothesis $(H O)$ was rejected in the reason of significance mean difference between RIL populations and within environments in the traits of pod length at $P \leq$ 0.05 level of significance, that means F-calculated greater than F-tabulated (P-value). Besides the remaining source of variations in the trait of pod, length showed that non-significance difference between treatments that means the F-test of the null hypothesis was accepted. The traits of pod width, pod thickness, pod length by width, thickness of pod shells and multiple-seed pods per plant showed that there was a significance difference between treatments, within environments and some traits expressed differences within years/seasons.

Table 1 GxE combined analysis of variances for Pod traits in the RIL population across two environments

\begin{tabular}{llllll}
\hline Pod-related traits & Source of Variations & df & MS & F-value & P-value \\
\hline Pod length $(\mathrm{mm})$ & RIL & 252 & 84.82 & 3.69 & $<.0001$ \\
& Env & 1 & 162.25 & 7.05 & 0.0009 \\
& Year & 1 & 14.50 & 0.63 & 0.5327 \\
& RIL x Env & 252 & 38.99 & 1.32 & 0.61 \\
& RIL x Yr & 450 & 14.07 & 0.47 & 0.85
\end{tabular}




\begin{tabular}{|c|c|c|c|c|c|}
\hline & Error & 702 & 23 & & \\
\hline \multirow[t]{6}{*}{ Pod width (mm) } & RIL & 252 & 7.20 & 2.52 & $<.0001$ \\
\hline & Env & 1 & 65.63 & 22.94 & $<.0001$ \\
\hline & Year & 1 & 79.32 & 27.73 & $<.0001$ \\
\hline & RIL x Env & 252 & 4.10 & 6.79 & 0.29 \\
\hline & RIL x Yr & 450 & 2.17 & 3.59 & 0.4022 \\
\hline & Error & 702 & 2.86 & & \\
\hline \multirow[t]{6}{*}{ Pod thickness (mm) } & RIL & 252 & 7.74 & 2.48 & $<.0001$ \\
\hline & Env & 1 & 20.14 & 6.45 & 0.0017 \\
\hline & Year & 1 & 3.08 & 0.99 & 0.3734 \\
\hline & RIL x Env & 252 & 4.53 & 906.95 & 0.0265 \\
\hline & RIL x Yr & 450 & 2.34 & 469.39 & 0.0368 \\
\hline & Error & 702 & 3.12 & & \\
\hline \multirow[t]{6}{*}{ Pod length by Width (mm) } & RIL & 252 & 0.52 & 4.08 & $<.0001$ \\
\hline & Env & 1 & 0.43 & 3.34 & 0.0362 \\
\hline & Year & 1 & 3.82 & 29.61 & $<.0001$ \\
\hline & RIL x Env & 252 & 0.25 & 0.63 & 0.7913 \\
\hline & RIL x Yr & 450 & 0.058 & 0.14 & 0.9913 \\
\hline & Error & 702 & 0.13 & & \\
\hline \multirow[t]{6}{*}{ Thickness of pod shells (mm) } & RIL & 252 & 0.16 & 1.38 & 0.0054 \\
\hline & Env & 1 & 2.41 & 20.57 & $<.0001$ \\
\hline & Year & 1 & 14.41 & 122.88 & $<.0001$ \\
\hline & RIL x Env & 252 & 0.05 & 0.43 & 1.0000 \\
\hline & RIL $x$ Yr & 450 & 0.05 & 0.42 & 1.0000 \\
\hline & Error & 702 & 0.12 & & \\
\hline \multirow[t]{6}{*}{ Number of pods per plant (No)) } & RIL & 252 & 46.24 & 1.11 & 0.2126 \\
\hline & Env & 1 & 56.19 & 1.34 & 0.2475 \\
\hline & Year & 1 & 404.55 & 9.67 & 0.0021 \\
\hline & RIL x Env & 252 & 26.16 & 0.63 & 0.9999 \\
\hline & RIL x Yr & 450 & 24.55 & 0.59 & 1.0000 \\
\hline & Error & 702 & 41.82 & & \\
\hline \multirow[t]{6}{*}{ Multiple-seed pods plant (No) } & RIL & 252 & 3.10 & 1.54 & 0.0003 \\
\hline & Env & 1 & 0.31 & 0.16 & 0.6929 \\
\hline & Year & 1 & 39.47 & 19.59 & $<.0001$ \\
\hline & RIL $x$ Env & 252 & 1.13 & 0.56 & 1.0000 \\
\hline & RIL x Yr & 252 & 1.03 & 0.51 & 1.0000 \\
\hline & Error & 702 & 2.01 & & \\
\hline \multirow[t]{6}{*}{ Pod weight per plant (g) } & RIL & 252 & 48.30 & 1.09 & 0.2372 \\
\hline & Env & 1 & 900.64 & 20.41 & $<.0001$ \\
\hline & Year & 1 & 316.83 & 7.18 & 0.0079 \\
\hline & RIL x Env & 251 & 28.13 & 0.64 & 0.9998 \\
\hline & RIL x Yr & 450 & 23.67 & 0.54 & 1.0000 \\
\hline & Error & 702 & 44.14 & & \\
\hline
\end{tabular}

For seed related-trait analysis of variances results shown that there were a mean difference between treatments and within environments at $\mathrm{P} \leq 0.05$ percentage level of significance in the trait of seed length, seed width, seed thickness. Some seed related traits like seed weight per plant and shelling percentage cannot express mean differences between treatments that indicated the null hypothesis was accepted.

Table 2 GxE Combined analysis of variances (ANOVA) for seed traits in the RIL population 


\begin{tabular}{|c|c|c|c|c|c|}
\hline Seed-related traits & Source of Variations & $\overline{d f}$ & MS & $\begin{array}{l}F- \\
\text { value }\end{array}$ & $P$ P-value \\
\hline \multirow[t]{6}{*}{ Seed length $(\mathrm{mm})$} & RIL & 252 & 10.21 & 2.87 & $<.0001$ \\
\hline & Env & 1 & 109.19 & 30.69 & $<.0001$ \\
\hline & Year & 1 & 0.005 & 0.00 & 0.9984 \\
\hline & RIL $x$ Env & 251 & 4.78 & 0.52 & 0.8343 \\
\hline & RIL x Yr & 450 & 2.86 & 0.31 & 0.9270 \\
\hline & Error & 702 & 9.24 & & \\
\hline \multirow[t]{6}{*}{ Seed width $(\mathrm{mm})$} & RIL & 252 & 1.70 & 1.67 & $<.0001$ \\
\hline & Env & 1 & 36.00 & 35.13 & $<.0001$ \\
\hline & Year & 1 & 5.72 & 5.59 & 0.0039 \\
\hline & RIL $x$ Env & 251 & 1.14 & 57.45 & 0.1049 \\
\hline & RIL x Yr & 450 & 0.95 & 47.89 & 0.1148 \\
\hline & Error & 702 & 0.02 & & \\
\hline \multirow[t]{6}{*}{ Seed thickness (mm) } & RIL & 252 & 1.26 & 1.69 & $<.0001$ \\
\hline & Env & 1 & 45.15 & 60.33 & $<.0001$ \\
\hline & Year & 1 & 9.71 & 12.98 & $<.0001$ \\
\hline & RIL x Env & 251 & 0.83 & 10.38 & 0.2435 \\
\hline & RILx Yr & 450 & 0.70 & 8.80 & 0.2638 \\
\hline & Error & 702 & 0.08 & & \\
\hline \multirow[t]{6}{*}{ Seed length/width (mm) } & RIL & 252 & 0.13 & 2.55 & $<.0001$ \\
\hline & Env & 1 & 0.11 & 1.98 & 0.1393 \\
\hline & Year & 1 & 0.29 & 5.43 & 0.0046 \\
\hline & RIL x Env & 251 & 0.10 & 1.26 & 0.6262 \\
\hline & RIL x Yr & 450 & 0.03 & 0.36 & 0.9026 \\
\hline & Error & 702 & 0.08 & & \\
\hline \multirow[t]{6}{*}{ Seed weight/plant (g) } & RIL & 252 & 21.65 & 1.04 & 0.3667 \\
\hline & Env & 1 & 482.59 & 23.27 & $<.0001$ \\
\hline & Year & 1 & 57.84 & 2.79 & 0.0961 \\
\hline & RIL x Env & 251 & 12.58 & 0.61 & 1.0000 \\
\hline & RIL x Yr & 450 & 11.81 & 0.57 & 1.0000 \\
\hline & Error & 702 & 20.74 & & \\
\hline \multirow[t]{6}{*}{ Shelling percentage (\%) } & RIL & 252 & 108.23 & 1.00 & 0.4958 \\
\hline & Env & 1 & 58.01 & 0.54 & 0.4645 \\
\hline & Year & 1 & 1532.14 & 14.17 & 0.0002 \\
\hline & RIL x Env & 251 & 50.77 & 0.47 & 1.0000 \\
\hline & RIL x Yr & 450 & 41.79 & 0.39 & 1.0000 \\
\hline & Error & 702 & 108.09 & & \\
\hline
\end{tabular}

The comparison of pod and seed-related traits across two environments

The pod and seed-related traits generated from Baoding and Handan environments were shown slight difference between environments, so this result indicated that most of agronomic traits had stability performance and environments effect was less. According to (Nucci, Narvaez, and Krettenauer 2014) the simple standard deviation or coefficient of variation values $(\mathrm{CV})$ indicated that the degree of a good index 
of reliability or the precision of the experiments and controlling of experimental errors. The cv can be expresses the experimental errors as the percentage of its means, that means the higher the cv value the less reliability of the experiment. As many field experiment experiences in from different researchers and scientists in different part of the world, the acceptable cv values ranging from 0-6 percent for variety development trials, 10-12 percent for fertilizer trials and 13-15 percent for pesticide and herbicide trials, meanwhile sometimes our cv values depends on the agronomic traits behavior and the situation of the experimental places so in the present study our cv values had a good precision and reliability across the two tested environments, however the cv values Baoding was a little bit greater than in Handan. According to the standardization of $\mathrm{cv}$ values for crop breeding programs our cv values in Baoding was ranging from 2.04-19.80 percent and Handan ranged from 3.58-10.56 percent. The relative coefficient of correlation determination R-squared $\left(\mathrm{R}^{2}\right)$ values ( 0 to 1$)$ in pod and seed related traits indicated that in Baoding except pod length by pod width and seed length by seed width traits the remaining traits showed strong correlation values $\left(\mathrm{R}^{2}>0.75\right)$ with dependent and independent variables, in Handan pod length by pod width and pod length traits shown less relative determination correlation values, but the remaining pod and seed-related traits expressed strong correlation indexing values (table 9). So, when compared two locations data the trait pod length by pod width had very low relative correlation determination value. In Baoding the traits of pod length, seed length and seed thickness had expressed perfect correlation determination r-squared values $(\mathrm{R} 2>0.95)$ than other traits, meanwhile in Handan only seed length had perfect correlation determination value ${ }^{[168]}$. The trait seed length had scored highest relative determination values across Baoding (0.99) and Handan (0.96) environments, this indicates this trait had good stability and promising performance and it did not affected by environmental variations (table 10).

Table 3 Descriptive statistical analysis of phenotypic traits of RILs with parents in two environments

\begin{tabular}{llllllllll}
\hline Environment & Traits & P1 & P2 & Range & Mean & SD & LSD & CV & R $^{\mathbf{2}}$ \\
\hline Baoding & PL & 33.9 & 39.0 & $32.3-40.3$ & 36.45 & 3.02 & 2.61 & 2.04 & 0.97 \\
& PWD & 13.5 & 15.8 & $13.4-17.0$ & 14.66 & 1.52 & 3.20 & 6.21 & 0.85 \\
& PT & 13.4 & 15.7 & $13.0-16.2$ & 14.60 & 1.34 & 2.24 & 4.36 & 0.90 \\
& PLW & 2.53 & 2.50 & $2.4-2.7$ & 2.51 & 0.13 & 0.71 & 8.11 & 0.05 \\
& SL & 13.8 & 19.0 & $12.4-20.5$ & 16.43 & 3.06 & 1.41 & 2.44 & 0.99 \\
& SWD & 8.0 & 8.9 & $6.8-11.1$ & 8.50 & 1.50 & 3.86 & 12.95 & 0.78 \\
& ST & 7.4 & 8.4 & $6.7-9.3$ & 7.93 & 0.96 & 1.03 & 3.71 & 0.96 \\
& SLW & 1.7 & 2.2 & $1.7-2.8$ & 1.96 & 0.42 & 1.36 & 19.80 & 0.66 \\
\hline Handan & PL & 34.2 & 33.2 & $33.2-34.2$ & 33.7 & 0.70 & 5.04 & 6.26 & 0.73 \\
& PWD & 12.8 & 14.4 & $12.8-14.4$ & 13.6 & 1.13 & 1.77 & 5.47 & 0.87 \\
& PT & 13.2 & 15.6 & $13.2-15.6$ & 14.4 & 1.69 & 1.17 & 3.58 & 0.93 \\
& PLW & 2.7 & 2.3 & $2.3-2.7$ & 2.5 & 0.28 & 0.42 & 8.47 & 0.20
\end{tabular}




$\begin{array}{lllllllll}\text { SL } & 13.4 & 16.3 & 13.4-16.3 & 14.8 & 2.05 & 1.92 & 5.33 & 0.96 \\ \text { SWD } & 8.1 & 9.3 & 8.1-9.3 & 8.7 & 0.84 & 2.03 & 10.56 & 0.79 \\ \text { ST } & 7.2 & 8.9 & 7.2-8.9 & 8.0 & 1.20 & 0.73 & 4.12 & 0.94\end{array}$

$\boldsymbol{P L}$ pod length, $\boldsymbol{P W D}$ pod width, $\boldsymbol{P T}$ pod thickness, $\boldsymbol{P L W}$ pod length by width ratio, $\boldsymbol{S} \boldsymbol{L}$ seed length, $\boldsymbol{S W D}$ seed width, $\boldsymbol{S T}$ seed thickness, $\boldsymbol{S} \boldsymbol{L} \boldsymbol{W}$ seed length by width ratio, $\boldsymbol{P} \mathbf{1}$ parent-1, $\boldsymbol{P} 2$ parent-2, $\boldsymbol{S} \boldsymbol{D}$ standard deviation, $\boldsymbol{L} \boldsymbol{S D}$ least significance difference, $C \boldsymbol{V}$ coefficient of variation, $\boldsymbol{R}^{2} \mathrm{R}$-square

\section{Pearson's correlation analysis}

Genotype by environment (GxE) combined Pearson's correlation coefficient values $(-1$ and +1$)$ from table-10 indicated that majority of the correlation matrix between the pod and seed-related traits were had positive correlations. The trait pod length (PL) positively correlated with seed length (SL), pod length by pod width ration (PLW), pod thickness (PT), pod width (PWD), seed width (SWD), seed thickness (ST), seed length by seed width ration (SLW), thickness of pod shells (TPS), multiple seed number of pods per plant (MSNP) and pod weight per plant (PWP) but it was negatively correlated with shelling percentage per plant (SP). The trait pod width was positively associated with pod thickness, seed length, seed width, seed thickness, thickness of pod shells, pod weight per plant, seed weight per plant but this agronomic trait negatively or indirectly correlated with pod length by width ratio, pod number per plant, multiple seeds pod number per plant and shelling percentage. The trait pod thickness directly correlated with seed length, seed width, seed thickness, the thickness of pod shells, pod weight per plant, seed weight per plant, pod length and pod width, but it was negatively correlated with pod length by width ratio, pod number per plant, multiple seedpod numbers per plant and shelling percentage. The trait pod length by width ratio had directly proportioned with pod length, seed length, and seed length by width ratio, pod numbers per plant, multiple seedpod numbers per plant, pod weight per plant, seed weight per plant and shelling percentage but it was negatively correlated with pod width, pod thickness, seed width, seed thickness and a thickness of pod shells. The seed length phenotypic trait was positively correlated with seed width, seed thickness, seed length by width ratio, thickness of pod shells, pod weight per plant, seed weight per plant, pod length by width ratio, pod thickness, pod width and pod length but this trait was inversely associated with pod number per plant, multiple seedpod number plant and pod shells per plant. Seed width traits positively correlated with seed thickness, thickness of pod shells, pod weight per plant, seed weight per plant, shelling percentage per plant, seed length, pod thickness, pod width and pod length, but it had negative correlation with seed length by width ratio, pod number per plant, multiple seedpod number per plant and pod length by width ratio. The trait seed thickness directly and positively correlated with thickness of pod shells, pod weight per plant, seed weight per plant, shelling percentage, seed width, seed length, pod 
thickness, pod width and pod length, despite it was negatively associated with seed length by width ratio, pod number per plant, multiple seedpod number plant and pod length by width. Pod weight per plant directly proportioned to seed weight per plant, seed thickness, seed width, seed length, pod length by width ratio, pod thickness, pod width, pod number per plant, thickness of pod shells and pod length but it had negatively correlated with seed length by width ratio. Seed weight was directly affected and related with pod weight per plant, pod number per plant, thickness of pod shells, seed thickness, seed width, seed length, pod length by width, pod thickness and pod width but it was negatively correlated with seed length by width ratio, regarding to the correlation matrix of phenotypic pod and seed-related traits clearly stated in table-4.

Table 4 GxE Combined Pearson's correlation coefficient analysis of pod and seed-related traits

\begin{tabular}{|c|c|c|c|c|c|c|c|c|c|c|c|c|c|c|}
\hline Traits & $\mathbf{P L}$ & PWD & PT & PLW & SL & SWD & ST & SLW & TPS & PNPP & MSNP & PWP & SWP & SP \\
\hline$\overline{\mathbf{P L}}$ & 1 & & & & & & & & & & & & & \\
\hline PWD & $0.43^{\mathrm{a}}$ & 1 & & & & & & & & & & & & \\
\hline PT & $0.50^{\mathrm{a}}$ & $0.84^{\mathrm{a}}$ & 1 & & & & & & & & & & & \\
\hline PLW & $0.54^{\mathrm{a}}$ & -0.36 & -0.19 & 1 & & & & & & & & & & \\
\hline SL & $0.61^{\mathrm{a}}$ & $0.59^{\mathrm{a}}$ & $0.65^{\mathrm{a}}$ & $0.11^{\mathrm{b}}$ & 1 & & & & & & & & & \\
\hline SWD & $0.24^{\mathrm{a}}$ & $0.63^{\mathrm{a}}$ & $0.58^{\mathrm{a}}$ & -0.25 & $0.51^{\mathrm{a}}$ & 1 & & & & & & & & \\
\hline ST & $0.27^{\mathrm{a}}$ & $0.57^{\mathrm{a}}$ & $0.54^{\mathrm{a}}$ & -0.17 & $0.56^{\mathrm{a}}$ & $0.66^{\mathrm{a}}$ & 1 & & & & & & & \\
\hline SLW & $0.24^{\mathrm{a}}$ & 0.02 & 0.08 & $0.21^{\mathrm{a}}$ & $0.30^{\mathrm{a}}$ & -0.23 & -0.01 & 1 & & & & & & \\
\hline TPS & $0.19^{\mathrm{a}}$ & $0.53^{\mathrm{a}}$ & $0.46^{\mathrm{a}}$ & -0.19 & $0.30^{\mathrm{a}}$ & $0.32^{\mathrm{a}}$ & $0.45^{\mathrm{a}}$ & $0.25^{\mathrm{a}}$ & 1 & & & & & \\
\hline PNPP & 0.04 & -0.12 & -0.11 & $0.13^{\mathrm{a}}$ & -0.12 & -0.04 & -0.06 & -0.08 & -0.05 & 1 & & & & \\
\hline MSNP & $0.43^{\mathrm{a}}$ & -0.10 & -0.06 & $0.50^{\mathrm{a}}$ & -0.05 & -0.18 & -0.14 & 0.08 & -0.10 & $0.26^{a}$ & 1 & & & \\
\hline PWP & $0.39^{\mathrm{a}}$ & $0.27^{\mathrm{a}}$ & $0.29^{\mathrm{a}}$ & $0.19^{\mathrm{a}}$ & $0.27^{\mathrm{a}}$ & $0.24^{\mathrm{a}}$ & $0.23^{\mathrm{a}}$ & 0.03 & $0.16^{\mathrm{a}}$ & $0.76^{\mathrm{a}}$ & $0.35^{\mathrm{a}}$ & 1 & & \\
\hline SWP & $0.34^{\mathrm{a}}$ & $0.17^{\mathrm{a}}$ & $0.19^{\mathrm{a}}$ & $0.22^{\mathrm{a}}$ & $0.22^{\mathrm{a}}$ & $0.26^{\mathrm{a}}$ & $0.25^{\mathrm{a}}$ & -0.04 & $0.08^{\mathrm{b}}$ & $0.74^{\mathrm{a}}$ & $0.36^{\mathrm{a}}$ & $0.95^{\mathrm{a}}$ & 1 & \\
\hline SP & -0.11 & -0.36 & -0.36 & $0.16^{\mathrm{a}}$ & -0.04 & $0.19^{\mathrm{a}}$ & $0.12^{\mathrm{a}}$ & -0.21 & -0.22 & 0.06 & 0.07 & 0.03 & $0.26^{\mathrm{a}}$ & 1 \\
\hline
\end{tabular}

$\boldsymbol{P} \boldsymbol{L}=$ Pod length, $\boldsymbol{P} \boldsymbol{W}=$ Pod width, $\boldsymbol{P} \boldsymbol{T}=$ Pod thickness, $\boldsymbol{P} \boldsymbol{L} \boldsymbol{W}=$ Pod length by width, $\boldsymbol{S} \boldsymbol{L}=$ Seed length, $\boldsymbol{S} \boldsymbol{W}=$ Seed width, $\boldsymbol{S} \boldsymbol{T}=$ Seed thickness, $\boldsymbol{S} \boldsymbol{L} \boldsymbol{W}=$ Seed length by width, ${ }^{\text {a }}$ correlation is significant at $\mathbf{0 . 0 1}$ level, ${ }^{\mathbf{b}}$ correlation is significant at $\mathbf{0 . 0 5}$ level and ${ }^{\mathbf{n s}}$ correlations are non-significant at $0.01 \& 0.05$ levels.

In the present study high genetic variability were indicated that those RIL populations showed they had genetic variability between them, thus the current variability had similarity with reported by Naazar et al (2000), Singh and Singh (1999), John et al (2006), Kadam et al (2007), and Khote et al (2009) for plant height and pod yield per plant. The highly heritable characters with high genetic advance as percent of mean could be further improved through individual plant selection (John et al 2013). Genetic advance measures the expected genetic progress that would be resulted from selecting the best-performed genotypes for a given characters (Allard, 1960). The genetic gain that can be obtained from a particular trait through selection is the product of its heritability, phenotypic standard deviation and selection differential (Burton and Devane 1953).

Table 5 GxE Combined estimation of genetic advance under selection, genotypic and phenotypic variability, genotypic and phenotypic coefficient of variability, and heritability 


\begin{tabular}{lllllllllll}
\hline Traits & $\boldsymbol{\sigma}^{\mathbf{2}}$ & $\boldsymbol{\sigma}_{\mathbf{e}}^{\mathbf{2}}$ & $\boldsymbol{\sigma}_{\mathbf{e r}}^{\mathbf{2}}$ & $\boldsymbol{\sigma}_{\mathbf{y r}}^{\mathbf{2}}$ & $\boldsymbol{\sigma}_{\mathbf{p}}^{\mathbf{p}}$ & $\boldsymbol{\sigma}_{\mathbf{G x E}}$ & $\mathbf{G C V}$ & $\mathbf{P C V}$ & $\mathbf{G A}$ & $\mathbf{G A M}$ \\
\hline PL & 7.40 & 0.97 & 29.38 & 0.92 & 8.37 & 0.00 & 22.47 & 25.40 & 10.71 & 32.49 \\
PWD & 0.35 & 0.16 & 2.50 & 0.11 & 0.51 & 0.00 & 2.77 & 4.05 & 2.31 & 18.17 \\
PT & 0.43 & 0.20 & 2.85 & 0.14 & 0.63 & 0.00 & 3.17 & 4.65 & 2.49 & 18.29 \\
PLW & 0.05 & 0 & 0.18 & 0.00 & 0.05 & 0.00 & 2.09 & 2.09 & 0.96 & 36.55 \\
SL & 0.69 & 0.12 & 3.59 & 0.20 & 0.80 & 0.00 & 4.54 & 5.30 & 3.52 & 23.26 \\
SWD & 0.08 & 0.05 & 0.64 & 0.17 & 0.13 & 0.00 & 1.08 & 1.73 & 1.13 & 14.88 \\
ST & 0.06 & 0.06 & 0.59 & 0.04 & 0.12 & 0.00 & 0.78 & 1.60 & 0.81 & 11.23 \\
SLW & 0.01 & 0.00 & 0.09 & 0.00 & 0.01 & 0.00 & 0.61 & 0.62 & 0.63 & 30.98 \\
TPS & 0.02 & 0.00 & 0.08 & 0.03 & 0.02 & 0.00 & 2.05 & 2.53 & 0.54 & 56.87 \\
PNPP & 3.33 & 0.05 & 32.91 & 1.03 & 3.38 & 0.00 & 23.66 & 23.99 & 12.02 & 85.28 \\
MSNP & 0.40 & 0 & 1.51 & 0.08 & 0.40 & 0.00 & 30.44 & 30.44 & 2.81 & 215.44 \\
PWP & 3.79 & 1.71 & 33.13 & 1.35 & 5.51 & 0.00 & 28.43 & 41.29 & 8.66 & 64.90 \\
SWP & 1.64 & 0.92 & 15.07 & 1.29 & 2.57 & 0.00 & 19.04 & 29.75 & 5.48 & 63.49 \\
\hline
\end{tabular}

$\sigma_{g}^{2}$ Genetic variance, $\sigma_{e}^{2}$ Environmental variance, $\sigma_{e r}^{2}$ Error variance, $\sigma_{y r}^{2}$ Year variance, $\sigma_{p}^{2}$ Phenotypic variance, $\sigma_{G \times E}^{2}$ Genotype by environment interaction variance, $\boldsymbol{G C V}$ Genotypic coefficient of variability, PCV Phenotypic coefficient of variability, $\boldsymbol{G A}$ Genetic advance/genetic gain, and $\boldsymbol{G A M}$ Genetic advance as percent of mean. PL Pod length, $\boldsymbol{P W D}$ Pod width, $\boldsymbol{P T}$ Pod thickness, $\boldsymbol{P L W}$ Pod length by width, $\boldsymbol{S} \boldsymbol{L}$ Seed length, $\boldsymbol{S W D}$ Seed width, $\boldsymbol{S} \boldsymbol{T}$ Seed thickness, $\boldsymbol{S} \boldsymbol{L} \boldsymbol{W}$ Seed length by width, TPS Thickness of pod shells, $\boldsymbol{P N P P}$ Pod number per plant, MSNP Multiple seed number of pods per plant, $\boldsymbol{P W P}$ Pod weight per plant, $S W P$ Seed weight per plant.

The highest genetic variation was found in the traits of pod length (7.4), pod weight per plant (3.79), number of pods per plant (3.33), and seed weight per plant (1.64). In this experiment the effects of the environment was slightly low however in the traits of pod weight per plant, pod length and seed weight per plant relatively moderate variation than the remaining traits, because the yield is the cumulative effect of many economically important traits. In the present study the highest experimental error have recorded in the traits of pod weight per plant, pod number per plant, pod length, seed weight per plant, seed length, pod thickness and pod width, the rest traits had low experimental errors.

Table 6 The comparative statement of the previously investigated reports of phenotypic coefficient of variation $(\mathbf{P C V})$ and genotypic coefficient of variation $(\mathbf{G C V})$ on pod and seed traits

\begin{tabular}{|c|c|c|}
\hline Traits & Components & References \\
\hline \multirow[t]{5}{*}{ Pod yield } & High (PCV) & Raut et al. 2010; Yadlapalli 2014; Patidar et al. 2014; Darvhankar et al. 2016 \\
\hline & Moderate (PCV) & John et al. 2012;Sabiel et al. 2014 \\
\hline & High (GCV) & Raut et al. 2010; Yadlapalli 2014; Patidar et al. 2014 \\
\hline & Moderate (GCV) & Darvhankar et al. 2016 \\
\hline & Low (GCV) & John et al. 2012; Sabiel et al. 2014 \\
\hline \multirow[t]{4}{*}{$\begin{array}{l}\text { Mature pods per } \\
\text { plant }\end{array}$} & High (PCV) & $\begin{array}{l}\text { Shoba et al. 2009; Raut et al. 2010; Padmaja et al. 2013b; Nath U.K and } \\
\text { Alam(Cui et al. 2020) M.S, } 2002 \text { Padmaja et al. 2013a;Yadlapalli 2014; } \\
\text { Patidar et al. 2014; Rao et al. 2014;Shashikumara et al. } 2016\end{array}$ \\
\hline & Moderate (PCV) & Patil et al. 2014 \\
\hline & High $(\mathrm{GCV})$ & $\begin{array}{l}\text { Nath U.K and Alam M.S, 2002; Shoba et al. 2009; Raut et al. 2010; Padmaja } \\
\text { et al. 2013a; Yadlapalli 2014; Patidar et al. 2014; Rao et al. 2014; } \\
\text { Shashikumara et al. } 2016\end{array}$ \\
\hline & Moderate (GCV) & Padmaja et al. 2013b; Patil et al. 2014 \\
\hline \multirow{2}{*}{$\begin{array}{l}\text { Immature pods } \\
\text { per plant }\end{array}$} & High (PCV) & Raut et al. 2010; Padmaja et al. 2013a \\
\hline & High (GCV) & Raut et al. 2010; Padmaja et al. 2013a \\
\hline
\end{tabular}




\begin{tabular}{|c|c|c|}
\hline \multirow[t]{2}{*}{$\begin{array}{l}\text { 100-pod weight } \\
\text { (g) }\end{array}$} & Moderate (PCV) & $\begin{array}{l}\text { Nath U.K and Alam M.S, 2002; John et al. 2013; Patil et al. 2014; Darvhankar } \\
\text { et al. } 2016\end{array}$ \\
\hline & Moderate (GCV) & $\begin{array}{l}\text { Nath U.K and Alam M.S, 2002; John et al. 2013; Patil et al. 2014; Darvhankar } \\
\text { et al. } 2016\end{array}$ \\
\hline \multirow{6}{*}{$\begin{array}{l}\text { 100-seed weight } \\
(\mathrm{g})\end{array}$} & High (PCV) & Shoba et al. 2009; Padmaja et al. 2013a; Padmaja et al. 2013b \\
\hline & Moderate (PCV) & John et al. 2013; Yadlapalli 2014; Patil et al. 2014; Rao et al. 2014 \\
\hline & Low (PCV) & John et al. 2011; John et al. 2012; Patidar et al. 2014; Sabiel et al. 2014 \\
\hline & High (GCV) & Shoba et al. 2009; Padmaja et al. 2013a; Padmaja et al. 2013b \\
\hline & Moderate (GCV) & $\begin{array}{l}\text { Shoba et al. 2009; John et al. 2013; Yadlapalli 2014; Patil et al. 2014; Rao et } \\
\text { al. } 2014\end{array}$ \\
\hline & Low $(\mathrm{GCV})$ & John et al. 2011; John et al. 2012; Patidar et al. 2014; Sabiel et al. 2014 \\
\hline \multirow[t]{4}{*}{ Pod length } & High (PCV) & Shoba et al. 2009 \\
\hline & Moderate (PCV) & Shoba et al. 2009 \\
\hline & High (GCV) & Shoba et al. 2009 \\
\hline & Low (GCV) & Shoba et al. 2009 \\
\hline \multirow[t]{3}{*}{ Pod width } & Moderate (PCV) & Shoba et al. 2009 \\
\hline & Moderate (GCV) & Shoba et al. 2009 \\
\hline & Low (GCV) & Shoba et al. 2009 \\
\hline \multirow[t]{5}{*}{$\begin{array}{l}\text { Pod yield per } \\
\text { plant }\end{array}$} & High (PCV) & $\begin{array}{l}\text { Nath U.K and Alam M.S, 2002; Shoba et al. 2009; John et al. 2013; Padmaja } \\
\text { et al. 2013a; Patidar et al. } 2014\end{array}$ \\
\hline & Moderate (PCV) & John et al. 2011; Patil et al. 2014; Rao et al. 2014; \\
\hline & High (GCV) & $\begin{array}{l}\text { Nath U.K and Alam M.S, 2002; Shoba et al. 2009; John et al. 2013; Padmaja } \\
\text { et al. 2013a; Patidar et al. } 2014\end{array}$ \\
\hline & Moderate (GCV) & Patil et al. 2014; Rao et al. 2014 \\
\hline & Low (GCV) & John et al. 2011 \\
\hline \multirow[t]{6}{*}{$\begin{array}{l}\text { Seed yield per } \\
\text { plant }(\mathrm{g})\end{array}$} & High (PCV) & $\begin{array}{l}\text { Shoba et al. 2009; Raut et al. 2010; John et al. 2011; John et al. 2012; John et } \\
\text { al. 2013; Patidar et al. 2014; Darvhankar et al. } 2016\end{array}$ \\
\hline & Moderate (PCV) & Patil et al. 2014; Rao et al. 2014 \\
\hline & Low (PCV) & Patidar et al. 2014 \\
\hline & High (GCV) & Shoba et al. 2009; Raut et al. 2010; John et al. 2013; Patidar et al. 2014 \\
\hline & Moderate (GCV) & Patil et al. 2014; Rao et al. 2014; Darvhankar et al. 2016 \\
\hline & Low (GCV) & John et al. 2011; John et al. 2012; Patidar et al. 2014 \\
\hline \multirow{6}{*}{$\begin{array}{l}\text { Sound mature } \\
\text { seeds/plant }(\%)\end{array}$} & High (PCV) & Padmaja et al. 2013a; Padmaja et al. 2013b \\
\hline & Moderate (PCV) & John et al. 2013; Darvhankar et al. 2016; \\
\hline & Low (PCV) & John et al. 2011; John et al. 2012; Patidar et al. 2014; Patil et al. 2014; \\
\hline & High (GCV) & Padmaja et al. 2013a; Padmaja et al. 2013b \\
\hline & Moderate (GCV) & Darvhankar et al. 2016 \\
\hline & Low (GCV) & $\begin{array}{l}\text { John et al. 2011; John et al. 2012; John et al. 2013; Patidar et al. 2014; Patil et } \\
\text { al. 2014; }\end{array}$ \\
\hline \multirow[t]{6}{*}{ Shelling $(\%)$} & High (PCV) & Raut et al. 2010 \\
\hline & Moderate (PCV) & $\begin{array}{l}\text { Nath U.K and Alam M.S, 2002; Raut et al. 2010; John et al. 2013; } \\
\text { Shashikumara et al. 2016; Darvhankar et al. } 2016\end{array}$ \\
\hline & Low (PCV) & $\begin{array}{l}\text { John et al. 2011; John et al. 2012; Padmaja et al. 2013a; Padmaja et al. 2013b; } \\
\text { Patidar et al. 2014; Patil et al. 2014; Sabiel et al. 2014; Rao et al. } 2014\end{array}$ \\
\hline & High (GCV) & Raut et al. 2010 \\
\hline & Moderate (GCV) & $\begin{array}{l}\text { Nath U.K and Alam M.S, 2002; Raut et al. 2010; John et al. 2013; } \\
\text { Shashikumara et al. } 2016\end{array}$ \\
\hline & Low $(\mathrm{GCV})$ & $\begin{array}{l}\text { Raut et al. 2010; John et al. 2011; John et al. 2012; Padmaja et al. 2013a; } \\
\text { Padmaja et al. 2013b; Patidar et al. 2014; Patil et al. 2014; Sabiel et al. 2014; } \\
\text { Rao et al. 2014; Darvhankar et al. 2016 }\end{array}$ \\
\hline \multirow{2}{*}{$\begin{array}{l}\text { Immature seeds } \\
\text { per plant }\end{array}$} & High (PCV) & Padmaja et al. 2013a \\
\hline & High $(\mathrm{GCV})$ & Padma \\
\hline Seed uniformity & High (PCV) & Patidar et al. 2014 \\
\hline
\end{tabular}




\section{Heritability and genetic advance}

The quantitative trait inheritance or heritability can be estimated from the given field experiment data on the observed and expected relationship between relatives of the population. The expected resemblance between relatives of the population depends on the assumptions regarding to the characters under environmental and genetic causes.

Robinson et al. (1949) suggested and recommended that the estimated percentage of heritability values of both narrow sense and broad sense have been categorized as low (0-30\%), moderate (30-60\%), and high ( $\geq 60 \%$ ). In the present study the highest narrow sense heritability values were existed in the traits of seed length (66\%), pod length by width (87\%), and pod thickness (93\%), meanwhile the moderate narrow sense heritability values have been scored in multiple seedpods per plant (36\%), pod length (47\%), and seed length by width (55\%), but the rest pod and seed-related traits showed low narrow sense resemblance relations within recombinant populations. In table four as we mentioned many of pod and seed seedrelated traits showed low heritability values, in our understanding the iffy causes of this low narrow sense resemblance relative values were; (1) the additive gene effect was very low, (2) non-additive gene action in the pollution were very high, (3) many of pod and seed-related traits were highly subjected to the given environmental variations and genotype by environmental interaction might be high, and (4) perhaps high experimental error plus the inclusive of soil factors and unstable weather conditions. The highest broad sense heritability values had been shown in the traits of seed length (99\%), seed length by width (99\%), number of pods per plant (95\%), shelling percentage (94\%), pod thickness (93\%), thickness of pod shells (92), seed weight per plant (89\%), seed thickness (87\%), seed width (83\%), multiple seedpods per plant (79\%), and pod weight per plant (75\%) and the moderate broad sense heritability values found in pod length (47\%), but the traits of pod width (2\%) had shown very low broad sense and narrow sense heritability values. Some pod traits such as; pod length (47\%), pod width (2\%), pod length by width (87\%), and pod thickness (93) had shown similar narrow sense and broad sense heritability values, this indicates except additive gene effect other gene effects masked and genotype by environment interaction had no significant effect.

According to Johnson et al. (1955) stated that, in our study the highest expected genetic advance selection values or high genetic gain values were existed in the traits of pod length (32.49), seed length (23.26), pod thickness, pod width, multi-seedpods per plant, number of pods per plant, pod weight per plant, seed weight per plant, pod length by pod width ratio, seed thickness. The highest genetic advance 
as percent of mean values scored in the traits of multiple seedpods per plant (215.44), number of pods per plant (85.28), pod weight per plant (64.90), seed weight per plant (63.49), thickness of pod shells (56.87), pod length by width (36.55), seed length by width (30.98), seed length (23.26), in addition moderate genetic advance as percent of means have been found in pod thickness (18.29), pod width (18.17), seed width (14.88), and seed thickness (11.23) traits. None of traits had low genetic advance values, so the present study had high genetic gain values.

High heritability combined with high genetic advance was considered as an indication of additive genetic variance (Johanson et al. 1955). However, it has been reported that in many crop including peanut heritability values were highly influenced by the environmental variations (Lin et al. 1971; Singh \& Oswalt 1991). In the present study the highest broad sense heritability values coupled with high genetic gain were estimated and identified in the traits of multiple seedpods per plant, number pods per plant, pod weight plant, seed weight per plant, thickness of pod shells, pod length by width, seed length by width, seed length, and some traits had moderate genetic advance as percent of means coupled with high broad sense heritability such as seed width, seed thickness, and pod thickness; similarly in the past other scientists estimated and reported that heritability and genetic advance as percent of mean values from pod and seed related traits in peanut for instance; Shashikumara et al. (2016) were reported in the three inbred line cross high heritability values coupled with high genetic advance as percent of mean, were existed in pod yield, that would be indicated that direct selection applied for pod yield and seed-related traits were more effective in the given populations (Golakia et al. 2005 and John et al. 2013). Similarly Narasimhulu et al (2012) were reported that high broad sense heritability coupled with high genetic advance, as percent mean was existed in pod yield, seed yield per plant and shelling percentage traits. Veeramani et al (2005) were also recorded high broad sense heritability and genetic advance for number of pods per plant and seed yield characters. John et al (2011) were reported high broad sense heritability and genetic advance for harvest index. This indicated that additive gene action plays a vital role for controlling pod and seedrelated traits hence individual plant selection would be effective for these pod and seed-related traits. In pod and pod-related traits high genetic gain or genetic advance as percent of mean values reported in number of mature pods per plant, number of immature pods per plant, hundred pod yield, pod yield per plant (Anon et al. 2013) and Shashikumara et al. (2016) they have been also reported that the highest genetic gain was observed in pod traits from three peanut recombinant inbred line populations. For comparison and discussion table two comprised previously investigated heritability values both broad sense and narrow sense. 
Table 7 The comparative statement of the past finding reports of heritability ( $\boldsymbol{H}$-broad sense and $\boldsymbol{h}$-narrow sense) and genetic advance as percent of mean $(\mathbf{G})$ or genetic gain values on pod and seed traits

\begin{tabular}{|c|c|c|}
\hline Traits & components & References \\
\hline \multirow[t]{7}{*}{ Pod yield } & $\operatorname{High}(\mathrm{H})$ & $\begin{array}{l}\text { Lin et al. 1971; Reddy 1968; Majumdar et al. 1969; Dixit et al. 1970; Sangha 1973b; Patra 1975; } \\
\text { Sandhu and Khera 1976; Lakshmaiah 1978; Gibori et al. 1978; Faujdar Singh and D.L. Oswalt } \\
\text { 1991; Nath U.K and Alam M.S, 2002; Raut et al. 2010; Jogloy et al. 2011; Padmaja et al. 2013a; } \\
\text { John et al 2013; Patidar et al. 2014; Yadlapalli 2014; Shashikumara et al. } 2016\end{array}$ \\
\hline & Moderate $(\mathrm{H})$ & Jogloy et al. 2011; Shashikumara et al. 2016 \\
\hline & Low $(\mathrm{H})$ & Bernard 1960; Lin 1966; John et al. 2011; Jogloy et al. 2011; John et al. 2012 \\
\hline & High (h) & Wynne and Rawling 1978; Cahaner 1978 \\
\hline & Moderate (h) & Basu et al. 1986a \\
\hline & $\operatorname{High}(\mathrm{G})$ & $\begin{array}{l}\text { Sabiel et al. 2014; Yadlapalli 2014; Patidar et al. 2014; Shashikumara et al. 2016; Darvhankar et } \\
\text { al. } 2016\end{array}$ \\
\hline & Low $(\mathrm{G})$ & John et al. 2012 \\
\hline \multirow[t]{3}{*}{$\begin{array}{l}\text { Mature pods } \\
\text { per plant }\end{array}$} & $\operatorname{High}(\mathrm{H})$ & $\begin{array}{l}\text { Kulkarni and Albuquerque 1967; Majumdar et al. 1969; Lin et al.1971; Basu and Ashokraj 1969; } \\
\text { Alam et al. 1985; Sandhu and Khera 1976; Sivasubramaniam et al. 1977; Nath U.K and Alam } \\
\text { M.S, 2002; Shoba et al. 2009; Raut et al. 2010; Padmaja et al. 2013a; John et al 2013; Patil et al. } \\
\text { 2014; Patidar et al. 2014; Yadlapalli 2014; Rao et al. } 2014\end{array}$ \\
\hline & $\operatorname{High}(\mathrm{G})$ & $\begin{array}{l}\text { Dholaria and Joshi 1972; Sangha 1973a; Kushwaha and Tawar 1973; Alam et al. 1985; Nath } \\
\text { U.K and Alam M.S, 2002; Shoba et al. 2009; Raut et al. 2010; Padmaja et al. 2013a; Yadlapalli } \\
\text { 2014; Patil et al. 2014; Patidar et al. 2014; Rao et al. 2014; Shashikumara et al. 2016; Prabhu et } \\
\text { al. } 2017\end{array}$ \\
\hline & Moderate $(\mathrm{G})$ & Padmaja et al. 2013b \\
\hline \multirow{5}{*}{$\begin{array}{l}\text { Immature } \\
\text { pods per } \\
\text { plant }\end{array}$} & High $(\mathrm{H})$ & Raut et al. 2010; John et al. 2013; Padmaja et al. 2013a \\
\hline & High $(\mathrm{H} \& \mathrm{G})$ & Dholaria and Joshi 1972; Sangha 1973a; Kushwaha and Tawar 1973; Alam et al. 1985 \\
\hline & Low $(\mathrm{H})$ & Lin et al. 1971 \\
\hline & Moderate (h) & John et al. 2011; John et al 2013 \\
\hline & $\operatorname{High}(\mathrm{G})$ & Padmaja et al. 2013a \\
\hline \multirow[t]{5}{*}{$\begin{array}{l}\text { 100-pod } \\
\text { weight }(g)\end{array}$} & High $(\mathrm{H})$ & $\begin{array}{l}\text { Cahaner 1978; Basu and Ashokraj 1969; Dixit et al. 1970; Nath U.K and Alam M.S, 2002; Patil } \\
\text { et al. } 2014\end{array}$ \\
\hline & Moderate $(\mathrm{H})$ & John et al. 2013; Darvhankar et al. 2016 \\
\hline & Low $(\mathrm{H})$ & Hammons 1974; Lakshmaiah 1978; Xiang et al. 1984 \\
\hline & $\operatorname{High}(\mathrm{G})$ & Nath U.K and Alam M.S, 2002; John et al. 2013; Patil et al. 2014 \\
\hline & Moderate $(\mathrm{G})$ & Darvhankar et al. 2016 \\
\hline \multirow[t]{7}{*}{$\begin{array}{l}\text { 100-seed } \\
\text { weight }(\mathrm{g})\end{array}$} & High $(\mathrm{H})$ & $\begin{array}{l}\text { Basu and Ashokraj 1969; Dixit et al. 1970; Sangha 1973b; Jogloy et al. 2011; Padmaja et al. } \\
\text { 2013a; John et al. 2013; Patil et al. 2014; Rao et al. } 2014\end{array}$ \\
\hline & Moderate $(\mathrm{H})$ & Alam et al. 1985; Shoba et al. 2009; Jogloy et al. 2011; Patidar et al. 2014; Yadlapalli 2014 \\
\hline & Low $(\mathrm{H})$ & Shoba et al. 2009; John et al. 2011; Jogloy et al. 2011; John et al. 2012; \\
\hline & Low $(\mathrm{h})$ & John et al. 2011 \\
\hline & $\operatorname{High}(\mathrm{G})$ & $\begin{array}{l}\text { Dholaria and Joshi 1972; Sangha 1973a; Kushwaha and Tawar 1973; Badwal et al. 1967; } \\
\text { Badwal and Gupta 1968; Shoba et al. 2009; Padmaja et al. 2013a; Padmaja et al. 2013b; } \\
\text { Yadlapalli 2014; Patil et al. 2014; Rao et al. } 2014\end{array}$ \\
\hline & Moderate $(\mathrm{G})$ & Alam et al. 1985; Shoba et al. 2009; John et al. 2013; Patidar et al. 2014; \\
\hline & Low $(\mathrm{G})$ & John et al. 2011; Sabiel et al. 2014 \\
\hline \multirow[t]{5}{*}{ Pod length } & High $(\mathrm{H})$ & Kushwaha and Tawar 1973; Shoba et al. 2009 \\
\hline & Low $(\mathrm{H})$ & Sibale 1985; Shoba et al. 2009 \\
\hline & High (h) & Wynne and Rawling 1978 \\
\hline & $\operatorname{High}(\mathrm{G})$ & Shoba et al. 2009 \\
\hline & Low $(\mathrm{G})$ & Shoba et al. 2009 \\
\hline \multirow[t]{4}{*}{ Pod width } & High $(\mathrm{H})$ & Shoba et al. 2009 \\
\hline & Moderate $(\mathrm{H})$ & Shoba et al. 2009 \\
\hline & $\operatorname{High}(\mathrm{G})$ & Shoba et al. 2009 \\
\hline & Moderate $(\mathrm{G})$ & Shoba et al. 2009 \\
\hline
\end{tabular}




\begin{tabular}{|c|c|c|}
\hline & Low $(\mathrm{G})$ & Shoba et al. 2009 \\
\hline Pod breadth & $\operatorname{High}(\mathrm{H})$ & Kushwaha and Tawar 1973 \\
\hline \multirow{2}{*}{$\begin{array}{l}\text { Seeds per } \\
\text { pod }\end{array}$} & $\operatorname{High}(\mathrm{H})$ & Nath U.K and Alam M.S, 2002 \\
\hline & Low $(\mathrm{H})$ & Hammons 1974 \\
\hline \multirow{5}{*}{$\begin{array}{l}\text { Pod yield } \\
\text { per plant }\end{array}$} & $\operatorname{High}(\mathrm{H})$ & John et al 2013;Patil et al. 2014; Rao et al. 2014 \\
\hline & Moderate $(\mathrm{H})$ & Shoba et al. 2009 \\
\hline & Low $(\mathrm{h})$ & John et al. 2011 \\
\hline & $\operatorname{High}(\mathrm{G})$ & $\begin{array}{l}\text { Nath U.K and Alam M.S, 2002; Shoba et al. 2009; John et al. 2013; Padmaja et al. 2013a; } \\
\text { Patidar et al. 2014; Patil et al. 2014; Rao et al. } 2014\end{array}$ \\
\hline & Low $(\mathrm{G})$ & John et al. 2011 \\
\hline \multirow{6}{*}{$\begin{array}{l}\text { Seed yield } \\
\text { per plant }\end{array}$} & High $(\mathrm{H})$ & Raut et al. 2010; Padmaja et al. 2013a; John et al 2013; Patil et al. 2014; Rao et al. 2014; \\
\hline & Moderate $(\mathrm{H})$ & Shoba et al. 2009; Darvhankar et al. 2016 \\
\hline & Low $(\mathrm{H})$ & John et al. 2011 \\
\hline & $\operatorname{High}(\mathrm{G})$ & $\begin{array}{l}\text { Shoba et al. 2009; John et al. 2013; Patidar et al. 2014; Patil et al. 2014; Rao et al. 2014; } \\
\text { Shashikumara et al. 2016; Darvhankar et al. } 2016\end{array}$ \\
\hline & Moderate (G) & Patidar et al. 2014 \\
\hline & Low $(\mathrm{G})$ & John et al. 2011; John et al. 2012 \\
\hline \multirow{7}{*}{$\begin{array}{l}\text { Sound } \\
\text { mature } \\
\text { seeds/plant } \\
(\%)\end{array}$} & High $(\mathrm{H})$ & John et al. 2013; Patidar et al. 2014 \\
\hline & Moderate $(\mathrm{H})$ & Patil et al. 2014 \\
\hline & Low $(\mathrm{H})$ & John et al. 2011; John et al. 2012; Darvhankar et al. 2016 \\
\hline & Low (h) & John et al. 2011 \\
\hline & $\operatorname{High}(\mathrm{G})$ & Padmaja et al. 2013a; Padmaja et al. 2013b \\
\hline & Moderate $(\mathrm{G})$ & John et al. 2013; Shashikumara et al. 2016;Darvhankar et al. 2016 \\
\hline & Low $(\mathrm{G})$ & John et al. 2011; Patidar et al. 2014; Patil et al. 2014 \\
\hline \multirow[t]{7}{*}{$\begin{array}{l}\text { Shelling } \\
\text { percentage }\end{array}$} & High $(\mathrm{H})$ & $\begin{array}{l}\text { Nath U.K and Alam M.S, 2002; John et al. 2013; Patil et al. 2014; Rao et al. 2014; Darvhankar et } \\
\text { al. } 2016\end{array}$ \\
\hline & Low $(\mathrm{H})$ & Raut et al. 2010; John et al. 2011; John et al. 2012; Padmaja et al. 2013a \\
\hline & Low (h) & John et al. 2011 \\
\hline & Moderate $(\mathrm{H})$ & Raut et al. 2010; Patidar et al. 2014 \\
\hline & $\operatorname{High}(\mathrm{G})$ & Nath U.K and Alam M.S, 2002; Shashikumara et al. 2016 \\
\hline & Moderate (G) & John et al. 2013; Patidar et al. 2014; Patil et al. 2014; Rao et al. 2014; Darvhankar et al. 2016 \\
\hline & Low $(\mathrm{G})$ & John et al. 2011; Padmaja et al. 2013a; Padmaja et al. 2013b; Sabiel et al. 2014 \\
\hline \multirow{2}{*}{$\begin{array}{l}\text { Immature } \\
\text { seeds per } \\
\text { plant }\end{array}$} & $\operatorname{High}(\mathrm{H})$ & Padmaja et al. 2013a \\
\hline & $\operatorname{High}(\mathrm{G})$ & Padmaja et al. 2013a \\
\hline \multirow{2}{*}{$\begin{array}{l}\text { Seed } \\
\text { uniformity }\end{array}$} & $\operatorname{High}(\mathrm{H})$ & Patidar et al. 2014 \\
\hline & $\operatorname{High}(\mathrm{G})$ & Patidar et al. 2014 \\
\hline
\end{tabular}

\section{Gene effects and genetic variance components}

Many researchers have been attempting to identify genetic variability and environmental influences that would be existed in the given population; nevertheless, they may not be in a position to accurate prediction of variations either directly or indirectly only using phenotypic data. However, this situation cannot hamper to evaluate and estimate the relative gene effects and environment variation in the 
phenotype variance components. The efficiency of genetic variability can be exploited through selection and it depends upon the heritability of individual characters from the given populations (Bilgin et al. 2010) and it gives an indication of how a given traits would be respond to selection (Falconer and Mackey, 1996).

Anon et al. (2013) were reported the estimation of observed genetic variability is difficult, because it is subjected to environmental variation so due to this reason variance component becomes heritable and nonheritable. The process of breeding in the existed population is primarily conditioned by the magnitude and nature of interactions of genotypic and environmental variations from a given agronomic traits. Moreover, it is important to partition the observed variability into its heritable and non-heritable components and to have an understanding of parameters like genetic coefficient of variation, heritability and genetic advance or genetic gains.

Table 8 Estimated genetic variances based on REML model using North Carolina one (NC-I) mating design and parent offspring regression analysis

\begin{tabular}{llllllll}
\hline Traits & $\boldsymbol{\sigma}^{\mathbf{2}}$ A & $\boldsymbol{\sigma}^{\mathbf{2}}$ AxE & $\boldsymbol{\sigma}^{\mathbf{2} D}$ & $\boldsymbol{\sigma}^{\mathbf{2}} \mathbf{D x E}$ & $\boldsymbol{h}^{\mathbf{2}}$ & $\boldsymbol{H}^{\mathbf{2}}$ & $\mathbf{D r}$ \\
\hline SL & 2.52 & 0.00 & 1.32 & 0.003 & 66 & 99 & 1.02 \\
SWD & 0.12 & 0.13 & 0.49 & 0.00 & 16 & 83 & 2.85 \\
SLW & 0.05 & 0.00 & 0.04 & 0.00 & 55 & 99 & 1.27 \\
ST & 0.15 & 0.08 & 0.43 & 0.00 & 23 & 87 & 2.39 \\
SWP & 4.39 & 1.32 & 10.08 & 0.56 & 27 & 89 & 2.14 \\
PL & 21.48 & $\mathbf{0 . 0 0}$ & $\mathbf{0 . 0 0}$ & $\mathbf{0 . 0 0}$ & $\mathbf{4 7}$ & $\mathbf{4 7}$ & 0.00 \\
PWD & 0.04 & $\mathbf{0 . 0 0}$ & $\mathbf{0 . 0 1}$ & $\mathbf{0 . 0 0}$ & $\mathbf{2}$ & $\mathbf{2}$ & 0.63 \\
PLW & 0.24 & $\mathbf{0 . 0 1}$ & $\mathbf{0 . 0 0}$ & $\mathbf{0 . 0 2}$ & $\mathbf{8 7}$ & $\mathbf{8 7}$ & 0.00 \\
PT & 5.76 & $\mathbf{0 . 0 1}$ & $\mathbf{0 . 0 0}$ & $\mathbf{0 . 3 9}$ & $\mathbf{9 3}$ & $\mathbf{9 3}$ & 0.00 \\
TPS & 0.01 & 0.01 & 0.08 & 0.00 & 8 & 92 & 4.62 \\
MSNP & 0.72 & 0.42 & 0.87 & 0.00 & 36 & 79 & 1.55 \\
PWP & 8.04 & 10.39 & 22.84 & 0.00 & 19 & 75 & 2.38 \\
PNPP & 2.02 & 1.87 & 31.70 & 0.00 & 6 & 95 & 5.61 \\
SP & 6.39 & 4.79 & 63.11 & 0.00 & 9 & 94 & 4.45 \\
\hline
\end{tabular}

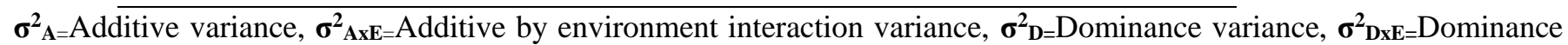
by environment interaction variance, $\boldsymbol{h}^{2}=$ Narrow sense heritability, $\boldsymbol{H}^{2}=$ Broad sense heritability, Dr=Dominance ratio. $\boldsymbol{S} \boldsymbol{L}$ seed length, $\boldsymbol{S W D}$ seed width, $\boldsymbol{S} \boldsymbol{L} \boldsymbol{W}$ seed length by width, $\boldsymbol{S T}$ seed thickness, $\boldsymbol{S W P}$ seed weight per plant, $\boldsymbol{P L}$ pod length, $\boldsymbol{P W D}$ pod width, $\boldsymbol{P L} \boldsymbol{W}$ pod length by width, $\boldsymbol{P T}$ pod thickness, $\boldsymbol{T P S}$ thickness of pod shells, $\boldsymbol{M S N P}$ multiple seedpods per

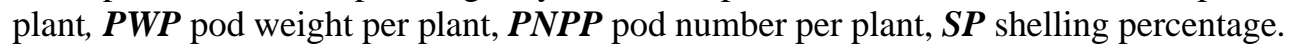

In the present study, the highest additive gene effect was existed in the traits of pod length (21.48), pod weight per plant (8.04), shelling percentage (6.39), and pod thickness (5.76), seed weight per plant (4.39), seed length (2.52), and pod number per plant (2.02). The highest dominant gene effect was found in the traits of shelling percentage (63.11), pod number per plant (31.70), pod weight per plant (22.84), seed weight per plant (10.08), and seed length (1.32). Additive gene action/effect interact with the existed environment that had high influence on pod weight per plant (10.39), shelling percentage (4.79), pod 
number plant (1.87), and seed weight per plant (1.32); besides the effect of dominance gene action with the interaction of the given environment had not shown significance change in all pod and seed-related traits. Estimation of heritability in the given populations depends on the partition and the association of observed phenotypic variation components into the reflection of unobserved genetic and environmental effects.

Table 9 The level of heredity/inheritance, gene effect, and environmental influences onto the RIL populations

\begin{tabular}{llllllll}
\hline Traits & $\boldsymbol{h}^{\mathbf{2}}$ & $\boldsymbol{H}^{\mathbf{2}}$ & \multicolumn{2}{c}{ Gene effect } & Genetic gain & Env. influence & GxE effect \\
\hline SL & High & High & Additive & Dominance & High & Low & Very low \\
SWD & Low & High & Non-additive & Non-dominance & Moderate & Low & Very low \\
SLW & High & High & Additive & Non-dominance & High & Low & Very low \\
ST & Low & High & No-additive & Non-dominance & Moderate & Low & Very low \\
SWP & Low & High & Non-additive & Dominance & High & Moderate & Very low \\
PL & Moderate & Moderate & Additive & Non-dominance & High & Moderate & Very low \\
PWD & Low & Low & Additive & Non-dominance & Moderate & Low & Very low \\
PLW & High & High & Additive & Non-dominance & High & Low & Very low \\
PT & High & High & Additive & Non-dominance & Moderate & Low & Very low \\
TPS & Low & High & No-additive & Non-dominance & High & Low & Very low \\
MSNP & Moderate & High & Additive & Dominance & High & Low & Very low \\
PWP & Low & High & Non-additive & Dominance & High & Moderate & Very low \\
PNPP & Low & High & Non-additive & Dominance & High & Low & Very low \\
\hline
\end{tabular}

$\boldsymbol{S L}$ seed length, $\boldsymbol{S W D}$ seed width, $\boldsymbol{S} \boldsymbol{L} \boldsymbol{W}$ seed length by width $\boldsymbol{S T}$ seed thickness, $\boldsymbol{S W P}$ seed weight per plant, $\boldsymbol{P L}$ pod

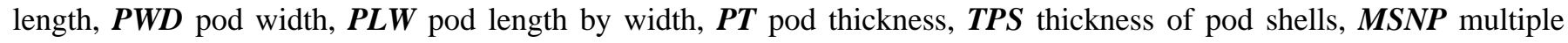

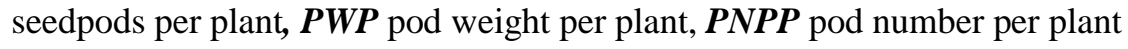

In the concept of quantitative genetics, the population structure was understood through the estimation of genetic variance components in the outcomes of allelic and non-allelic gene effects with the included of interaction effects called epistasis. Bateson (1909) has designated the interaction effects alleles from different loci to predicted epistasis allele effects. In the year of 1918, Fisher was attempting to partition the genetic variances components as additive (average effects of genetic alleles), dominant (interaction between alleles of the same locus) and epistatic (interactions between alleles in different loci), of which the latter was considered the most complex for trait inheritance studies (Fisher 1984). According to Bernardo (2002), epistatic effects can be exist when the sum of the individual effects of the loci are larger or smaller than the overall effects therefore; besides in the absence of epistatic effects, a single additivedominant model would be fully explain the expression of a traits. On the other hand, when epistasis is present, it can bias the estimates of additive and dominant genetic variance components, resulting in inaccurate estimates of important genetic parameters, such as heritability and expected response to selection (Antonio et al. 2012). In the present study the additive gene effects observed in the traits of seed length, seed length by width, pod length, pod width, pod length by width, pod thickness, thickness of pod 
shells, and multiple seedpods per plant. For more discussion and comparison, the following table five showed the statement of comparison our findings with previously investigated outcomes by different researchers in different time.

Table 10 Genetic variance components and gene effects on pod and seed-related traits

\begin{tabular}{lllll}
\hline Traits & Components & Gene effect & Envt. influence & References \\
\hline Total pods/ plant & High (G) & Additive & Low to moderate & Shashikumara et al. 2016 \\
Matured pods/plant & High (G) & Additive & Low & Shashikumara et al. 2016 \\
Seed yield/plant & High (G) & Additive & Low & Shashikumara et al. 2016 \\
Sound mature seed (\%) & Low to high (G) & Additive +Non-additive & Low & Shashikumara et al. 2016 \\
Pod yield/plant (g) & High (G) & Additive & Low & Sridharan and Marappan 1980; Basu et al. \\
& & & & 1987; Shashikumara et al. 2016; \\
& & Additive +Non-additive & Low & Mohammed et al. 1978 \\
Shelling (\%) & Non-additive & & Schilling 1986; Sandhu and Khera 1976 \\
Pod number/ plant & & Additive & Low & Shashikumara et al. 2016 \\
& & Non-additive & & Sandhu and Khera 1976; Dwivedi et al. \\
100 pod weight & & & 1989 \\
100 seed weight & & Non-additive & & Schilling 1986 \\
& & Additive & Sridharan and Marappan 1980 \\
Number of seeds/pod & & Additive +Non-additive & & Reddy et al. 1986 \\
Pod length & & Non-additive & & Sandhu and Khera 1976 \\
& & Non-additive & & Schilling 1986 \\
Pod size & & Additive & Dwivedi et al. 1989 \\
& & Non-additive & & Schilling 1986 \\
& & Additive +Non-additive & & Mohammed et al. 1978 \\
\hline
\end{tabular}

In the present study high narrow sense heritability coupled with high additive gene variance was recorded in pod thickness and seed length traits, pod length by width trait had high narrow sense heritability value but it had low additive genetic variance, moderate narrow sense heritability coupled with high additive genetic variance had been existed in the trait of pod length, this indicates the effect of the gene is additive gene effect, however sometimes this assumption affected by several uncertainty reasons, for instance the variation of the given environment, experimental errors and others, the remaining pod and seed traits had scored low narrow sense heritability values. Therefore, for selection we have been recommended the traits that should have high heritability values coupled with high additive genetic variances.

\section{Conclusion}

The highest broad sense heritability values coupled with high genetic gain were estimated in multiple seedpods per plant, number of pods per plant, pod weight plant, seed weight per plant, thickness of pod shells, pod length by width, seed length by width. The present study will be helpful for peanut 
improvement programs to harnessing heritability and genetic variability within and between individual populations.

\section{Acknowledgements}

Prof Dr. Liu Lifeng, and Dr. Yang Xinlei Peanut Molecular Research laboratory, Department of Crop Genetics and Breeding, College of Agronomy HeBAU, China.

\section{Funded}

This experiment was funded by the Chinese Ministry of Commerce and Finance (MOFCOM).

\section{Conflict of interest}

The author declared that no conflict of interests.

\section{References}

Anon. 2013. GENETIC VARIABILITY STUDIES IN DIFFERENT ADVANCED BREEDING GENOTYPES OF SPANISH BUNCH GROUNDNUT ( ARACHIS HYPOGEAE ) K . John, R . P . Vasanthi , K . Sireesha and T . Giridhara Krishna Regional Agricultural Research Station , Tirupati-517502 . Correspon.”(2002):185-87.

Anon. 2014. "GENETIC VARIABILITY AND CHARACTER ASSOCIATION STUDIES IN GROUNDNUT ( ARACHIS HYPOGAEA L .) Satish Yadlapalli. Regional Agricultural Research Station , Lam Farm , Guntur-34 , Andhra Pradesh , India Satish Yadlapalli Copyrights @ 2014 IJPAES ISSN 2231-44.” (cm):298-300.

Anon. n.d. "Genetic Variability, Heritability and Genetic Advance for Yield and Related Traits in Groundnut.Pdf."

Antonio, Marco, Acevedo Barona, José Manoel, Colombari Filho, Silva Santos, and Isaias Olívio Geraldi. 2012. “Epistatic Effects on Grain Yield of Soybean [ Glycine Max ( L .) Merrill ].” 231-36.

Cui, Yongtao, Xingming Hu, Guohua Liang, Anhui Feng, Fanmiao Wang, Shuang Ruan, Guojun Dong, Lan Shen, Bin Zhang, Dongdong Chen, Li Zhu, Jiang Hu, Yongjun Lin, Longbiao Guo, Makoto Matsuoka, and Qian Qian. 2020. “Production of Novel Beneficial Alleles of a Rice Yield-Related QTL by CRISPR/Cas9.” Plant Biotechnology Journal 18(10):198789. doi: $10.1111 /$ pbi.13370.

Directorate, Bera. 2016. "Evaluation of Genotypic Variations and Stability Analysis for Pod Yield in Recombinant Inbred Lines of Groundnut." (December).

Janila, Pasupuleti, S. N. Nigam, Manish K. Pandey, P. Nagesh, and Rajeev K. Varshney. 2013. “Groundnut Improvement: Use of Genetic and Genomic Tools.” Frontiers in Plant Science 4(February):23. doi: 10.3389/fpls.2013.00023.

Jogloy, C., P. Jaisil, C. Akkasaeng, T. Kesmala, and S. Jogloy. 2011. "Heritability and Correlation for Maturity and Pod Yield in Peanut." 7(2):134-40.

John, K., P. Raghava Reddy, K. Haripraad Reddy, P. Sudhakar, and N. P. Eswar Reddy. 2012. "Studies on Genetic Variability for Morphological, Water Use Efficiency, Yield and Yield Traits in Early Segregating Generation of Groundnut ( A Rachis Hypogaea L ).” 4(October):446-52. doi: 10.5897/IJBC11.200.

John, K., P. Raghava Reddy, P. Hariprasad Reddy, P. Sudhakar, N. P. Eswar Reddy, S. V. Agricultural College, and Andhra Pradesh. 2011. “GENETIC VARIABILITY FOR MORPHOLOGICAL, PHYSIOLOGICAL , YIELD AND YIELD 
TRAITS IN F 2 POPULATIONS OF GROUNDNUT ( A RACHIS HYPOGAEA L ) Ragional Agricultural Research Station, Tirupati-517502, Andhra Pradesh, India . Former Vice Chancellor, Acharya N .” (4):463-69.

Nucci, Larry, Darcia Narvaez, and Tobias Krettenauer. 2014. "Second Edition Second Edition.” Dairy Science \& Technology, CRC Taylor \& Francis Group (June):1-542.

Padmaja, D., Brahmeswara Rao, K. B. Eswari, and S. Madhusudhan Reddy. 2013. "Genetic Variability , Heritability for Late Leaf Spot Tolerance and Productivity Traits in a Recombinant Inbred Line Population of Groundnut ( Arachis Hypogaea L .)." 5(1):36-41.

Patidar, Satyanarayan, Prashant Kumar Rai, and Arvind Kumar. 2014. "Evaluation of Groundnut ( Arachis Hypogaea L .) Genotypes for Quantitative Character \& Yield Contributing Traits.” 4(7):500-504.

Patil, A. S., A. A. Punewar, H. R. Nandanwar, and K. P. Shah. 2014. "ESTIMATION OF VARIABILITY PARAMETERS FOR YIELD AND ITS COMPONENT TRAITS IN GROUNDNUT ( ARACHIS HYPOGAEA L . ).” 9(2):749-54.

Prabhu, R., R. Divyadharsini, and N. Manivannan. 2015. "Genetic Variability Analysis in F 3 Populations of Groundnut ( Arachis Hypogaea L . ).” 8(December):5958.

Rao, V. Thirumala, V. Venkanna, D. Bhadru, and D. Bharathi. 2014. "Studies on Variability, Character Association and Path Analysis on Groundnut ( Arachis Hypogaea L .).” 2(2):194-97.

Raut, R. D., L. K. Dhaduk, and J. H. Vachhani. 2010. "Studies on Genetic Variability and Direct Selections for Important Traits in Segregating Materials of Groundnut ( Arachis Hypogaea L .).” 6(1):234-37.

Sabiel, Salih A. I., Mohamed I. Ismail, Elgailani Abdalla, Khalid A. Osman, Plant Breeding Program, and Wad Medani. 2014. "International Journal of Environment." (3):16-23.

Shashikumara, P., B. G. Sanjeev, and P. Venkataravana. 2016. “Assessment of Genetic Variability and Identification of Transgressive Segregants for Pod Yield and Its Component Traits in F 2 Segregating Generation of Groundnut ( Arachis Hypogea L )." 6(4):53-60.

Shoba, D., N. Manivannan, and P. Vindhiyavarman. 2009. "Studies on Variability, Heritability and Genetic Advance in Groundnut ( Arachis Hypogaeae L .).” 74-77.

Singh, Faujdar, and D. L. Oswalt. 1991. "Genetics and Breeding of Groundnut.” (4).

Siva Subramanian S, Menon M (1973b). Heterosis and in breeding depression in rice. Madras Agric. J. 60:1139-1149.

Tripathi, A., Rajani, B., Ahirwal, R. P., Paroha, S., Sahu, R. and Ranganatha, A. R. G. 2013. Study on Genetic Divergence in Sesame (Sesamum indicum L.) Germplasm Based on Morphological and Quality Traits. The Bioscan. 8(4): 1387-1391.

Veeramani BB, Prakash M, Jagdeeshan S, Kavimani S, Saravanan K and Ganeshan J., 2005. Variability studies in M2 generation of groundnut (Arachis hypogaea L.). Legume Research 28(1): 68-70.

Wynne,J.C.,andGregory,W.C.,1981. Peanut breeding. Adv. Agron. 34, 39-72.

Wynne, J. C, and Rawling, J.O., 1978. Genetic variability and heritability for an inter cultivar cross of peanut. Peanut Science 5:23-26.

Xiang, R.Y., Li, X.Y., Ling, S.X., and Zheng, G.Y., 1984. Preliminary analysis of the F1s of high yielding Spanish-type groundnut cultivars crossed with rust resistant Valencia-types. Guangdong Nongye Kexue 2:18-22.

Yadlapalli Satish, 2014. Genetic variability and character association studies in groundnut (Arachis hypogaea L.). International journal of plant, animal and environmental science, 4(4). pp.298-300.

Zhang, X., Han, S., Tang, F., Xu, J., Liu, H., Yan, M., 2011. Genetic analysis of yield in peanut (Arachis hypogaea L.) 
using mixed model of major gene plus polygene. Afr. J. Biotechnol. 10,7126-7130. 